International Journal of Management (IJM)

Volume 12, Issue 9, September 2021, pp. 55-83, Article ID: IJM_12_09_006

Available online at https://iaeme.com/Home/issue/IJM?Volume $=12 \&$ Issue $=9$

ISSN Print: 0976-6502 and ISSN Online: 0976-6510

DOI: https://doi.org/10.34218/IJM.12.9.2021.006

C IAEME Publication

Scopus Indexed

\title{
A STUDY ON WOMEN ENTREPRENEUR'S AWARENESS ABOUT GOVERNMENT SCHEMES- SPECIAL REFERENCE TO CHENNAI DISTRICT, TAMIL NADU
}

\author{
G. Lakshmi Priya ${ }^{1}$, Dr. S. Smilee Bose ${ }^{2}$ \\ ${ }^{1}$ Full-Time Research Scholar, Department of Commerce, \\ St. Peter's Institute of Higher Education and Research, \\ St. Peters University, Tamil Nadu, India \\ ${ }^{2}$ Research Supervisor, Associate Professor, Department of Commerce, \\ St. Peter's Institute of Higher Education and Research, \\ St. Peters University, Tamil Nadu, India
}

\begin{abstract}
In recent times in India, Women Entrepreneurship has becoming an emerging trending pace in the development of economy of self, their family and nation. The state of Tamil Nadu is one of the best industrially developing area where, Women Entrepreneurs excel in Small scale industry. In the last two decades, Women are facing many opportunities in Entrepreneurship which not only increases their self-sufficiency, self-esteem, education and growth but also helps their families and employees. They play a significant role in creation of employment opportunities exclusively for Women Job seekers.

Though Women Entrepreneurs has positive impact on Entrepreneurship, they also face a lot of hurdles and problems especially in fund generation. Women Entrepreneurs must have good source of knowledge with regard to finance. For this, Government has introduced many financial schemes and training programmes among Women in order to promote Entrepreneurship which encourages them to earn self-income.

Now a days, Many Government as well as Non-Government agencies plays a vital role in Women Entrepreneurship in the form of providing training, Loan disbursement, economic development and merchandising. The purpose of this article is to study the level of awareness of Government schemes among Women Entrepreneurs in Chennai, Tamil Nadu. This paper discusses about various Government schemes available to Women Entrepreneurs and lists out successful Women Entrepreneurs in Chennai. The data has been collected from two hundred (respondents) Women Entrepreneurs in Chennai. The hypothesis will be tested at $0.05 \%$ level of significance.
\end{abstract}

Key words: Women Entrepreneurs, Entrepreneurship, Government Schemes, Training Programmes 
A Study on Women Entrepreneur's awareness about Government Schemes- Special Reference to Chennai District, Tamil Nadu

Cite this Article: G. Lakshmi Priya and S. Smilee Bose, A Study on Women Entrepreneur's awareness about Government Schemes- Special Reference to Chennai District, Tamil Nadu, International Journal of Management (IJM), 12(9), 2021, pp. 55-83.

https://iaeme.com/Home/issue/IJM?Volume=12\&Issue=9

\section{INTRODUCTION}

Women Entrepreneurs are represented as innovative Entrepreneurs who has creative thinking and capable of establishing and running business activity with confident, generation employment opportunities to others and economically independent by accepting their business risks. Women becomes Entrepreneurs either by chance of accepting challenges or force by family income or by creation for passion. The general inbuilt qualities for Women Entrepreneurs are desire to do something new, risk taker, coordinator, supervisor and capacity of contribution to both family and social life.

Presently, the emergence of Women Entrepreneurs in India has been significantly increases and considered as the major part in financial progress and economic development in our country. The entry of Women Entrepreneurs are observed in 1990's, after the introduction of Liberalization Globalization and Privatization (LPG). Earlier, Women Entrepreneurs exists in the business like Handicrafts, Stitching, Food caterings, embroideries, etc. and latter on they were shifted to Small Medium Enterprises (SMEs) related to Agro-based sector, Manufacturing sectors, Trading sectors and Service sectors.

Tamil Nadu, the state has been ranked third in the industrial development and has taken promoting measures for Entrepreneurship development among Women. It is reported that the State Tamil Nadu has more number of Women Entrepreneurs in India as compared to any other states in India. For the development of Women Entrepreneurs, Indian Government has taken steps in the form of financial Assistance and Subsidies for Entrepreneurs. Some of the schemes provided by the Government of Tamil Nadu are a) New Entrepreneurs Cum Enterprise Development Scheme (NEEDS)- to help first generation entrepreneurs who are Unemployed educated Youth b) Wind Mill scheme- to encourage Entrepreneurs to install Windmill for captive consumption of renewable energy. c) Entrepreneur Development Scheme (EDS)- to encourage entrepreneurship among persons who belongs to economically and socially disadvantaged background. d) Unemployed Youth Employment Generation Programme (UYEP) etc.

In this paper, an effort has been made to know the level of awareness among Women Entrepreneurs towards Government Schemes of Women Entrepreneurs in India and also suggests some ways for raising the level of awareness among Women Entrepreneurs.

\section{REVIEW OF LITERATURE}

Dr. Shrikrishna S. Mahajan, Mr. Chandrakant B. Kamble (2011)- "Government Support to Women Entrepreneurs: A Study of Programmes Implemented By Mavim". This study focussed on various schemes and programmes implemented by Mahila Arthik Vikas Mahamandal (MAVIM) for Women in Kolhapur District and its support to Entrepreneurship development among women.

Dr. A.S. Shiralashetti (2013)- "Awarness Level towards Government Schemes- A Study on Women Entrepreneurs of North Karnataka Districts" (Part of UGC Supported Major Research Project). This study analysed the level of awareness towards schemes of government. This study resulted that Women Entrepreneurs have high level of awareness towards Stree Shakti Scheme and low level of awareness towards Swarna Jayanthi Gram Swarojgar Yojana 
(SJGSY), Udyogini, Rastrya Mahila Kosh, and Prime Minister Employment Generation Programme (PMEGP).

Dr. Rajesh Chatterjee, Amit Kr. Deb (2013) - "Effect of Government Programmes on Entrepreneurship: A Study on NE India with Special Reference to Tripura". This study focused on various schemes of Government agencies for rural entrepreneurship development in Tripura. This study discussed the effect of government programmes on Socio-Economic status of rural entrepreneurs

M. Mahendran, R. Rajan Babu (2015) - "Financial Support and Schemes Availed to Women Entrepreneurs in Nagapattinam District Tamilnadu". This study discussed about financial supporting institutions and schemes offered to Women Entrepreneurs in Tamil Nadu and analysed the awareness and knowledge on schemes of Financial supporting institutions in Women Entrepreneurs. The researchers concluded that most of the Women Entrepreneurs are unaware of various schemes provided by the Government.

Haris Abrar Kashmiri, Rubeena Alchter (2017)- "Role of Government Policy in Entrepreneurship Development". This study discussed the role of Government policies in development of Entrepreneurship and its impact on economic development.

Sathiyabama P, Velmurugan R (2019)- "A Study on the Awareness of Indian Government Schemes among the Women Entrepreneurs of Coimbatore District". This study identified Women Entrepreneurs level of awareness of government schemes in Coimbatore district and also offered suitable suggestion to raise their awareness. The study resulted that most of Women Entrepreneurs are aware of Mudra Yojana Scheme for Women, Industrial Finance Corporation of India scheme of interest subsidy for Women Entrepreneurs, Annapurna Scheme etc. and suggested that Government has to conduct camps, advertisements etc. in order to create awareness of its schemes.

Dr. R. Paulmoni, Dr. P. Geetha (2019)- “ A Study on Women Entrepreneurs Awareness about Government Schemes- Special Reference To Kanniyakumari District". This study discussed about the awareness of Women Entrepreneurs on Government Schemes using rank method. This study result revealed that Mudra Yojana Scheme for Women got first rank, second rank for Annapurna Scheme, third rank got Micro Credit Scheme and Mahila Vikas Nithi has got last rank.

Dayananda Huded, Mallikarjun M. Maradi (2020) - "Skill Development Programmes for Women Entrepreneurship in India: A Case Study Ofrudset Vijayapur". This study discussed about various skills development programmes offered by RUDSET Vijayapur for Women Entrepreneurs and analysed the growth of training Women Entrepreneurs and Successful rate of Trained Women Entrepreneurs by providing developmrnt training programmes by RUDSET in Vijayapur district. This study revealed the result that majority of the women entrepreneurs were not taking advantages of RUDSET in the Vijayapur district and the percentage of settlement of women was decreased due to lack of interest in taking risk.

\section{OBJECTIVES OF THE STUDY}

- To examine the association between sources of awareness and awareness on government schemes.

- To Understand various Entrepreneurial training programmes taken by Women Entrepreneurs. 
A Study on Women Entrepreneur's awareness about Government Schemes- Special Reference to Chennai District, Tamil Nadu

\section{METHODOLOGY OF THE STUDY}

This study is based on both Primary and Secondary data sources. Primary data collected from two hundred Women Entrepreneurs in Chennai district, Tamil Nadu. Secondary data in the form of various related research articles, books, websites, journals, magazines etc.

The collected data are analysed using Statistical tools like one sample t-test for, one way ANOVA, Friedman test, Chi-Square and ANCOVA.

\subsection{Financial Supporting Schemes to Women Entrepreneurs in India}

The Government of India has supported Women Entrepreneurs by providing various financial assistance schemes and training through different department and Ministries. Some of the Schemes and trainings are listed below:

\section{Stand-Up India}

Stand-Up India schemes has been launched on $16^{\text {th }}$ January 2016 by hornarable Pime Minister Narendra Modi. This scheme provides bank loan between rs. 10 lakhs to rs. 1 crore. This is loan can be availed by atleast one Scheduled Caste/ Scheduled Tribe (SC/ST) and Women Entrepreneur for setting up new enterprise in the field of manufacturing, trading, services sector or Agri-allied activities. The Working capital limit is upto rs.1 million in the form of Cash Credit limit. The repayment tenure period is Maximum of 7 years with moratorium period up to 18 months. This scheme has the objective to encourage entrepreneurs to start-up new enterprises which in turn result in employment creation among them.

\section{Trade Related Entrepreneurship Assistance and Development (TREAD)}

This Scheme gives credit availability to interested Women through through Non- Government Organizations(NGOs). Women can receive support from registered NGOs either in the form of loan facility, counselling or training programmes, that creates opportunities to start proposed enterprise in order to provide pathway for women to take up non-Farm activities. The Government would grant loan of $30 \%$ of total cost of project by lending institutions and remaining $70 \%$ will be granted by NGOs to aid Women in establishing their business.

\section{Bharatiya Mahila Bank (BMB)}

Bharatiya Mahila Bank is special bank formed for empowerment of Women in India. The main objective of BMB is to focus on Women Entrepreneurship especially for Women who are economically backward, discriminated, deprived, unbanked, illiterate and rural women to make sure about their business development. This scheme grant collateral free loan amount upto one crore for setting up business like Beauty parlour, food business and Day care centers.

\section{Credit Guarantee Fund Trust for Micro and Small Enterprises (CGTMSE)}

Credit Guarantee Fund Trust for Micro and Small Enterprises was launched by Government of India on $30^{\text {th }}$ August 2000. The objective of this scheme is to make collateral free loan available to promote Micro and Small Scale Enterprise Sector. This scheme can be available to both New and Existing Enterprises.

\section{Akshaya Mahila Arthik Sahay Yojana (AMASY)}

AMASY scheme was offered by Bank of Baroda Bank to encourage Women Entrepreneurs in the field of Agriculture, Retail business and Cottage industry. There is no Collateral security required for availing loan under AMASY scheme. 


\section{Dena Shakti Scheme}

Dena Shakti Scheme was provided by Dena Bank with the objective to support Women financially to promote economic opportunities and economic empowerment of women in the field of Agriculture and allied activities, Micro and Small scale Manufacturing and Service enterprises, Retail business, Education and Accommodation. Interest rate is below $0.25 \%$ for women entrepreneurs who holds majority shares in the company.

\section{Stree Shakthi Package}

Stree Shakthi Scheme was initiated by State Bank of India (SBI) This scheme has been specially created for the women who wish to start new business or to expand their existing business. For availing loan Women must hold majority of shares in their company. The loan will be available to Women Entrepreneurs in the field of retail business, Professional business and Small Scale Industries. The interest rate is $0.5 \%$ for women who borrow above Rs. 2 and Collateral free security loan No specific spot rs. 5 lakhs. A special concession in the margin by $5 \%$.

\section{Cent Kalyani Scheme}

Cent Kalyani Scheme was introduced in Central Bank of India. The aim of this scheme is to fulfil Women's dream in establishing and expanding business by granting financial loans. Funds can be availed by Women to generate working capital, for purchase of machinery/ equipment of business or any other relevant business needs. Amount of Loan is upto rs. 100 lakhs with interest rate of $9.70 \%$ and marginal rate of $20 \%$.

\section{Swarna Jayanti Gram Swarozgar Yojana (SGSY)}

Swarna Jayanti Gram Swarozgar Yojana (SGSY) was launched by Government of India on $1^{\text {st }}$ April 1999. This was initiated to provide sustainable income to rural poor. By reconstructing Poverty Alleviation Programmes like IRDP, DWACRA, SITRA, GKY, TRYSEM, MWS etc. and Government of India has replaced SGSY Scheme. The eligibility for loan is applicable to people belong to poverty line with margin of $25 \%$.

\section{Rashtriya Mahila Kosh}

Rashtriya Mahila Kosh scheme is also known as the National Credit Fund for Women (NCFW), initiated by Government of India to access credit to poor and asset-less Women. It was launched on $30^{\text {th }}$ March 1993. The aim of this scheme is to generate income for poor women in Dairy, Agriculture, shop-keeping, vending and handicrafts.

\section{Pradhan Mantri MUDRA Yojna (PMMY)}

Mudra Yojna was introduced by Prime Minister Narendra Modi The aim of this Scheme is to provide funds to fulfil financial and non-financial requirement for Non-Corporate small businesses. This scheme helps Entrepreneurs who face finance problem in running their business.

\section{Prime Ministers Employment Generation Programme (PMEGP)}

This PMEGP Schemes was launched in 2008. It is a combination of major credit-linked subsidy scheme of Prime Minister's Rojgar Yojana (PMRY) and Rural Employment Generation Programme (REGP) in establishing Micro-enterprises for creating employment opportunities . The Scheme has been implemented through banks, District Industries Centres (DICs), State KVIC Directorates and State Khadi and Village Industries Boards (KVIBs) at the state level by Khadi and Village Industries Commission (KVIC) at the national level. 
A Study on Women Entrepreneur's awareness about Government Schemes- Special Reference to Chennai District, Tamil Nadu

\section{Indira Mahila Yojana}

The Indira Mahila Yojana (IMY) was launched on $20^{\text {th }}$ August. The aim of this scheme is to create awareness on income generation among the women from rural areas and urban slums and economic empowerment of women.

\section{Micro and Small Enterprise Cluster Development Programmes (MSE-CDP)}

This Scheme refer to a group of enterprises ,20 or more of enterprises producing same or similar products. MSE-CDP scheme is launched by Government of India and Ministry of Micro, Small and Medium Enterprises. The aim of this scheme is to assist financial and infrastructure needs of Micro, Small, Medium Enterprise Sector. This scheme facilitate Cluster Development Programme to enhance productivity and Stability of MSME sector.

\section{Mahila Udyam Nidhi Scheme}

Mahila Udyam Nidhi Schemes is offered under Small Industrial Development Bank of India (SIDBI) with an objective to encourage and nurture women entrepreneurs by providing financial assistance at concessional interest rates. This scheme is Availed to MSMEs to undertake service, manufacturing and production related activities. Women Entrepreneurs can get loan up to Rs. 1 million to start their own business or small scale enterprise. The interest rates offered may vary from bank to bank. The maximum loan repayment period offered under this scheme is up to 10 years with the moratorium pages up to 5 years.

\section{New Entrepreneurs cum Enterprise Development Scheme (NEEDS)}

NEEDS scheme has been promoted by Directorate of Industries and Commerce and Government of India. The objective of this scheme is to provide educated youth with opportunities for first generation entrepreneurship by providing capital and interest subsidy. This scheme is applicable for the person resident of Tamil Nadu for not less than 3 years. The minimum project cost is 5 lakhs and maximum of rs. 1 crore.

\subsection{Training Programmes}

\section{Start-Up India}

This Start-Up India scheme is an initiative launched by our Prime Minister for providing opportunities to young generation people to become industrialists and entrepreneurs who need to establish a Start-Up network. This program enables young people to start business by providing financial support by generating and implementing innovative ideas in the right direction.

\section{Pradhan Mantri Kaushal Vikas Yojana (PMKVY)}

Pradhan Mantri Kaushal Vikas Yojana (PMKVY) is an initiative programme implemented by the Government of India. This PMKVY scheme was launched under the New National Skill Development and Entrepreneurship Policy 2015 with an aim to offer a meaningful, industry relevant and skill-based training among youth. The Objectives of PMKVY is to encourage and develop skill among young people by providing them financial rewards for successful completion of their training programmes.

\section{Atal Innovation Mission (AIM)}

The Atal Innovation Mission (AIM) has been launched up by the NITI Aayog to promote innovation and entrepreneurship across all over the country. The objective of this programmes is to create and promote environment for innovation and entrepreneurship at school, 
universities, research institutions, Micro Small and Medium Enterprises and management level.

\section{Make in India Skill India - Kaushal Bharat Kushal Bharat}

Make in India Skill India - Kaushal Bharat Kushal Bharat was launched by Prime Minister Narendra Modi on July 15, 2015. This programmes consist of various initiatives like national Skill Development Mission, Pradhan Mantri Kaushal Vikas Yojana (PMKVY), skill loan scheme, national policy for skill development and Entrepreneurship, and rural India skill. The aim of this programmes is to monitor and provide training programmes for skill development among people by the year 2022 and focuses on the activity like like carpenters, cobblers, blacksmiths, nurses, tailors, etc. This programmes helps to create employment, develop Entrepreneurial quality, improves communication skills, managerial and personality development and make balanced growth in all the sectors.

\section{The Federation of Indian Women Entrepreneurs (FIWE)}

FIWE is a National Level Non-Governmental Organization established in 1999 and registered under Indian Societies Act of 1860. It is one of India's leading institution for entrepreneurship empowerment and development of women and youth. FIWE has been working with agencies of National \& International repute like Sector Skill Councils, Directorate General of Employment \& Training, Ministry of Skills Development \& Entrepreneurship, Small Industries Development Bank of India(SIDBI), National Bank for Agriculture and Rural Development(NABARD), etc. in formulating policy towards the growth and development of MSMEs.

\section{Support to Training and Employment Programme for Women (STEP)}

Support to Training and Employment Programme for Women scheme has been launched by Ministry of Women \& Child development. STEP Scheme aims to provide employment skills to women that enable women to become entrepreneurs. This Scheme has been commenced for the benefit women in the age group of 16 years or above across the country.

\section{ANALYSIS AND FINDINGS}

\subsection{Demographic Variables of the Respondents}

\section{Hypothesis}

$\mathrm{H}_{01}: \mu=$ Average age of the Respondent is 26 years.

$\mathrm{H}_{02}: \mu=$ Average Education Qualification of the Respondent has Post Graduation Degree.

$\mathrm{H}_{03}: \mu=$ Average Marital status of the Respondents are Married.

$\mathrm{H}_{04}: \mu=$ Average Type of family of the respondents belongs to joint family.

$\mathrm{H}_{05}: \mu=$ Average status of the respondents in their family is Head of the family.

$\mathrm{H}_{06}: \mu=$ Average experience of the respondent have 0-1 year of experience in business.

$\mathrm{H}_{07}: \mu=$ Average working hours of the respondent is less than 6 hours a day.

$\mathrm{H}_{08}: \mu=$ Average kind of Business run by the respondents is Manufacturing Business.

$\mathrm{H}_{09}: \mu=$ Average employment generated to others by respondents is 6- 10 employees. 
A Study on Women Entrepreneur's awareness about Government Schemes- Special Reference to Chennai District, Tamil Nadu

Table 1.1 Shows Demographic profile of the Respondents

- The distribution of respondents according to their age is given below.

- Since the p value (0. .203) is more than 0.05. Null Hypothesis is Accepted at 5\% level. Hence, Average age of the respondents is 26 years.

- Education Qualification is one of the prime necessities for Women Entrepreneurs as it enhances knowledge and confidence. The respondents under different levels of education are represented in the below Table 1.1

- Since the $p$ value is $(0.000)$ is less than $<0.05$. Null hypothesis is rejected at $5 \%$ level of significance. Hence, Average education qualification of the respondents does not have Post Graduate degree.

- Classification of respondents on the basis of their Marital Status as Married, Spinster, widow and divorcee showed in the below Table.

- Since the p value is $(0.000)$ less than $(<) 0.05$. Null Hypothesis is Rejected at $5 \%$ level. Hence, Average Martial status of Women Entrepreneurs are Spinster.

- Respondents are classified according to their type of family they belong. Classified as Joint family and Nuclear family is shown in the table below.

- Since the p value is $(0.000)$ less than $(<) 0.05$. Null Hypothesis is Rejected at $5 \%$ level. Hence, Average Type of family of the respondents belongs to Nuclear family.

- The distribution of respondents according to the status in their family. Calssifeied into Head of the family and Member in the family

- Since the p value is $(0.000)$ less than $(<) 0.05$. Null Hypothesis is Rejected at $5 \%$ level. Hence, Average status of the respondents in their family is Member of the family.

- Experience is considered as significant factor as it provides Women Entrepreneurs to make effective decisions on their own. The Experience of respondents in business is shown in the table 1.1

- Since the p value is $(0.000)$ less than $(<) 0.05$. Null Hypothesis is Rejected at $5 \%$ level. Hence, Average experience of the respondent have more than 1 year of experience in business.

- The success of Women Entrepreneurs lies in substantial work time on business. Working hours of the respondents in business is shown in the below table.

- Since the p value is $(0.000)$ less than $(<) 0.05$. Null Hypothesis is Rejected at $5 \%$ level. Hence, Average working hours of the respondent is not less than 6 hours a day.

- Type of business chosen by Women Entrepreneurs in running their business according to their skills, education, finances, and convenience are shown in the Table 1.1.

- Since the p value is $(0.000)$ less than $(<) 0.05$. Null Hypothesis is Rejected at $5 \%$ level. Hence, Average kind of Business run by the respondents is not Manufacturing Business.

- The size of a business is important because it significantly affects the efficiency and profitability of the Business. The Business size of the respondents in E Business is shown in the Table 1.1.

- Since the p value is $(0.000)$ less than $(<) 0.05$. Null Hypothesis is Rejected at $5 \%$ level. Hence, Average employment generated to others by respondents is not 6- 10 employees 
Table 1 Demographic factors of the Respondents

\begin{tabular}{|c|c|c|c|c|c|c|c|c|}
\hline $\begin{array}{c}\text { Demographic } \\
\text { variable }\end{array}$ & Group of data & \begin{tabular}{|c|} 
No. of \\
Respondents
\end{tabular} & $\begin{array}{c}\text { Mean } \\
\overline{\mathbf{x}}\end{array}$ & $\begin{array}{l}\text { Standard } \\
\text { Deviation }\end{array}$ & $\begin{array}{l}\text { Degree of } \\
\text { Freedom }\end{array}$ & $\begin{array}{c}\text { Test } \\
\text { Statistic }\end{array}$ & \begin{tabular}{c|} 
Sig.. \\
$(2$ \\
Tailed) \\
\end{tabular} & $\begin{array}{c}\text { Mean } \\
\text { Difference }\end{array}$ \\
\hline Age & Above 20 years & 200 & 26.39 & 4.2 & 199 & 1.28 & 0.20 & 0.385 \\
\hline Education & Below SSLC & 10 & \multirow[t]{5}{*}{3.25} & \multirow[t]{5}{*}{0.92} & \multirow[t]{5}{*}{199} & \multirow[t]{5}{*}{-569.90} & \multirow[t]{5}{*}{.000} & \multirow[t]{5}{*}{-36.75} \\
\hline \multirow[t]{4}{*}{ Qualification } & Pre- University & 14 & & & & & & \\
\hline & Under Graduate & 112 & & & & & & \\
\hline & Post Graduate & 44 & & & & & & \\
\hline & Professional & 20 & & & & & & \\
\hline \multirow[t]{4}{*}{ Marital Status } & Married & 88 & \multirow[t]{4}{*}{1.70} & \multirow[t]{4}{*}{0.757} & \multirow[t]{4}{*}{199} & \multirow[t]{4}{*}{-902.48} & \multirow[t]{4}{*}{0.000} & \multirow[t]{4}{*}{-48.30} \\
\hline & Spinster & 92 & & & & & & \\
\hline & Widow & 12 & & & & & & \\
\hline & Divorcee & 8 & & & & & & \\
\hline \multirow[t]{2}{*}{ Family Type } & Joint Family & 56 & \multirow[t]{2}{*}{1.72} & \multirow[t]{2}{*}{0.45} & \multirow[t]{2}{*}{199} & \multirow[t]{2}{*}{-3087.78} & \multirow[t]{2}{*}{0.000} & \multirow[t]{2}{*}{-98.28} \\
\hline & Nuclear Family & 144 & & & & & & \\
\hline \multirow[t]{2}{*}{$\begin{array}{l}\text { Status of the } \\
\text { Family }\end{array}$} & $\begin{array}{l}\text { Head of the } \\
\text { family }\end{array}$ & 73 & \multirow[t]{2}{*}{1.64} & \multirow[t]{2}{*}{0.483} & \multirow[t]{2}{*}{199} & \multirow[t]{2}{*}{-2882.27} & \multirow[t]{2}{*}{0.000} & \multirow[t]{2}{*}{-98.37} \\
\hline & $\begin{array}{l}\text { Member of the } \\
\text { family }\end{array}$ & 127 & & & & & & \\
\hline \multirow{4}{*}{$\begin{array}{l}\text { Experience in } \\
\text { business }\end{array}$} & $0-1$ year & 43 & 2.2500 & 0.98 & 199 & -692.01 & 0.000 & -692.01 \\
\hline & 1-3 Years & 97 & & & & & & \\
\hline & 3-5 years & 27 & & & & & & \\
\hline & Above 5 Years & 33 & & & & & & \\
\hline $\begin{array}{l}\text { Working } \\
\text { Hours (per }\end{array}$ & $\begin{array}{l}\text { Less than } 6 \\
\text { hours }\end{array}$ & 31 & 1.9100 & 0.46148 & 199 & -1933.399 & 0.000 & -63.09 \\
\hline day) & $\begin{array}{l}6 \text { hours- } 10 \\
\text { hours }\end{array}$ & 156 & & & & & & \\
\hline & above 10 hours & 13 & & & & & & \\
\hline $\begin{array}{l}\text { Kinds of } \\
\text { business }\end{array}$ & $\begin{array}{l}\text { Manufacturing } \\
\text { Business }\end{array}$ & 66 & 1.90 & 0.91882 & 199 & -586.42 & 0.000 & -38.10 \\
\hline & \begin{tabular}{|l|} 
Wholesale and \\
Retail business \\
\end{tabular} & 112 & & & & & & \\
\hline & \begin{tabular}{|l|} 
Health care, \\
Education and \\
social service \\
oriented business
\end{tabular} & 3 & & & & & & \\
\hline & \begin{tabular}{|l|} 
Agri-Allied \\
business
\end{tabular} & 14 & & & & & & \\
\hline & $\begin{array}{l}\text { Management and } \\
\text { personal service } \\
\text { business }\end{array}$ & 5 & & & & & & \\
\hline Business size & \begin{tabular}{|l|} 
Up to 5 \\
Employees \\
\end{tabular} & 93 & 1.7850 & 0.90 & 199 & -599.44 & 0.000 & -38.21 \\
\hline & \begin{tabular}{|l|}
6 to 10 \\
Employees
\end{tabular} & 71 & & & & & & \\
\hline & \begin{tabular}{|l}
$11-15$ \\
Employees
\end{tabular} & 22 & & & & & & \\
\hline & \begin{tabular}{|l|} 
above 20 \\
Employees
\end{tabular} & 14 & & & & & & \\
\hline
\end{tabular}

(Source: Primary)

Interpretation: From the above table 1.1, shows that

- Women in the age of 26 years are more likely to start their business.

- Women Entrepreneurs have good knowledge in running their business as majority of Women Entrepreneurs are educated at Under Graduate degree. 
A Study on Women Entrepreneur's awareness about Government Schemes- Special Reference to Chennai District, Tamil Nadu

- Majority of Women respondents are spinster in running their business. This shows that Women Entrepreneurs are more likely to run their business before marriage.

- Majority of Women respondents are from nuclear family. This shows that Women Entrepreneurs are likely to be independent and creative in order to overcome the challenges faced by them in family like lack of family support, difficult in managing work-life etc.

- The status of Women Entrepreneurs in their family is member in the family.

- Table above shows that Women Entrepreneurs have more than 1 year of business experience. This shows that majority of Women Entrepreneur's success depends on their experience in business.

- This above table shows that majority (77\%) of Women Entrepreneurs work average of 6 hours- 10 hours a day. It indicate that Women Entrepreneurs have flexibility in running their business.

- This above table shows that majority (56\%) of Women Entrepreneurs involve in Trade activities like whole sale and retail business followed by Manufacturing business (33\%) and Agri-Allied Business (7\%) and less involved in Management and personal service business $(2.5 \%)$ and Health care, Education and social service oriented business (1.5\%).

- This above table shows that majority (46\%) of the respondents provide employment opportunities up to 5 Employees. Women Entrepreneurs main contribution towards Economic growth is providing employment opportunities to others.

\subsection{Interrelationship between Investment made by Women Entrepreneurs in starting their business and Source of finance in running their business.}

\section{Hypothesis}

$\mathrm{H}_{0}$ : There is no significant association between Investment made by Women Entrepreneurs and source of finance for initial investment in their business.

$\mathrm{H}_{1}$ : There is a significant association between Investment made by Women Entrepreneurs and source of finance for initial investment in their business.

Table 2 Cross Tabulation of Sources of Finance of Business and Investment of the respondents in starting business

\begin{tabular}{|c|c|c|c|c|c|c|c|}
\hline \multicolumn{8}{|c|}{ Sources of Finance of Business * Investment of the respondents in starting business Crosstabulation } \\
\hline & & \multicolumn{5}{|c|}{ Investment of the respondents in starting business } & \multirow[b]{2}{*}{ Total } \\
\hline & & $\begin{array}{c}\text { up to } \\
\text { Rs. } 50,000\end{array}$ & \begin{tabular}{|l|} 
Rs.50.001 \\
- rs. \\
$2,50,000$
\end{tabular} & $\begin{array}{c}\text { Rs. } 2,50,000- \\
10,00,000\end{array}$ & $\begin{array}{c}\text { Rs. } 10,00,001- \\
15,00,000\end{array}$ & Above Rs.15,00,000 & \\
\hline \multirow{5}{*}{$\begin{array}{l}\text { Sources } \\
\text { of } \\
\text { Finance } \\
\text { of } \\
\text { Business }\end{array}$} & $\begin{array}{l}\text { Personal } \\
\text { Assets/Savings }\end{array}$ & 76 & 27 & 0 & 0 & 0 & 103 \\
\hline & $\begin{array}{l}\text { Loan from } \\
\text { Friends and } \\
\text { Relatives } \\
\end{array}$ & 19 & 22 & 0 & 0 & 0 & 41 \\
\hline & $\begin{array}{l}\text { Loan from } \\
\text { Commercial } \\
\text { Banks }\end{array}$ & 24 & 12 & 0 & 0 & 0 & 36 \\
\hline & $\begin{array}{l}\text { Loan from } \\
\text { Financial } \\
\text { Institutions } \\
\end{array}$ & 5 & 12 & 0 & 0 & 0 & 17 \\
\hline & Venture Capital & 2 & 1 & 0 & 0 & 0 & 3 \\
\hline Total & & 126 & 74 & 0 & 0 & 0 & 200 \\
\hline
\end{tabular}

(Source: Primary) 


\begin{tabular}{|l|c|c|c|c|c|}
\hline \multicolumn{7}{|c|}{ ANOVA } \\
\hline & Investment of the respondents in starting business \\
\hline & Sum of Squares & df & Mean Square & F & Sig. \\
\hline Between Groups & 4.31 & 4 & 1.08 & 4.962 & .001 \\
\hline Within Groups & 42.31 & 195 & 0.22 & & \\
\hline Total & 46.62 & 199 & & & \\
\hline
\end{tabular}

(Source: Primary)

Since, $\mathrm{P}$ value $(0.001)$ is $(<)$ less than 0.05 , Null hypothesis is rejected at $5 \%$ level of significance. Therefore, there is a significant association between Investment made by Women Entrepreneurs and source of finance for initial investment in their business.

Interpretation: The above table shows that there is strong relationship between investment made by the respondents and sources of finance for initial investment in business by the respondents. Half of the respondents invested their money from their personal savings and contributed in business up to rs.50,000.

\subsection{Reason for starting business}

\section{Hypothesis}

$\mathrm{H}_{0}$ : There is no significant difference in ranking of reason for starting business among Women Entrepreneurs.

$\mathrm{H}_{1}$ : There is a significant difference in ranking of reason for starting business among Women Entrepreneurs.

Table 3 Reason for starting business

\begin{tabular}{|c|l|c|c|}
\hline S.No & \multicolumn{1}{|c|}{ Reason for starting business } & Mean Rank & Rank \\
\hline 1 & Needed the money/ help family & 5.06 & 3 \\
\hline 2 & Try to do something new & 5.31 & 5 \\
\hline 3 & Self-status function & 4.95 & 2 \\
\hline 4 & providing employment to others & 4.64 & 1 \\
\hline 5 & To gain business knowledge & 5.97 & 8 \\
\hline 6 & To continue family business & 6.52 & 10 \\
\hline 7 & To become expert & 5.10 & 4 \\
\hline 8 & To be creative & 5.31 & 5 \\
\hline 9 & Flexibility in work & 5.65 & 7 \\
\hline 10 & To make profits and wealth & 6.50 & 9 \\
\hline
\end{tabular}

(Source: Primary)

\begin{tabular}{|l|c|}
\hline \multicolumn{2}{|c|}{ Test Statistics $^{\mathbf{a}}$} \\
\hline $\mathbf{N}$ & 200 \\
\hline Chi-Square & 81.20 \\
\hline Df & 9 \\
\hline Asymp. Sig. & 0.00 \\
\hline a. Friedman Test & \\
\hline
\end{tabular}

(Source: Primary)

Since the $\mathrm{p}$ value $(0.00)$ is less than $(<0.05)$. Null Hypothesis is rejected at $5 \%$ level of significance. Hence, There is a significant difference in ranking of reason for starting business among Women Entrepreneurs. 
A Study on Women Entrepreneur's awareness about Government Schemes- Special Reference to Chennai District, Tamil Nadu

Interpretation: We conclude that providing employment opportunity to others is the most attractive reason for women Entrepreneurs in starting their business.

\subsection{Interrelationship between Knowledge on various schemes available to Women Entrepreneurs and sources of awareness on various schemes}

\section{Hypothesis}

$\mathrm{H}_{01}$ : There is no significant association between awareness on Stand Up India scheme with sources of awareness among Women Entrepreneurs.

$\mathrm{H}_{02}$ : There is no significant association between awareness on TREAD (Trade Related Entrepreneurship Assistance and Development) scheme with sources of awareness among Women Entrepreneurs.

$\mathrm{H}_{03}$ : There is no significant association between awareness on Bharatiya Mahila Bank scheme with sources of awareness among Women Entrepreneurs.

$\mathrm{H}_{04}$ : There is no significant association between awareness on Akshaya Mahila Arthik Sahay Yojana (AMASY) scheme with sources of awareness among Women Entrepreneurs.

$\mathrm{H}_{05}$ : There is no significant association between awareness on Dena Shakti Scheme with sources of awareness among Women Entrepreneurs.

$\mathrm{H}_{06}$ : There is no significant association between awareness on Stree Shakthi Package scheme with sources of awareness among Women Entrepreneurs.

$\mathrm{H}_{07}$ : There is no significant association between awareness on Cent Kalyani Scheme with sources of awareness among Women Entrepreneurs.

$\mathrm{H}_{08}$ : There is no significant association between awareness on Can Mahila Scheme with sources of awareness among Women Entrepreneurs.

$\mathrm{H}_{09}$ : There is no significant association between awareness on Rashtriya Mahila Kosh scheme with sources of awareness among Women Entrepreneurs.

$\mathrm{H}_{010}$ : There is no significant association between awareness on Pradhan Mantri MUDRA Yojna (PMMY) scheme with sources of awareness among Women Entrepreneurs.

$\mathrm{H}_{011}$ : There is no significant association between awareness on Indira Mahila Yojana scheme with sources of awareness among Women Entrepreneurs.

$\mathrm{H}_{012}$ : There is no significant association between awareness on Shringaar and Annapurna Scheme from Bhartiya Mahila Bank scheme with sources of awareness among Women Entrepreneurs.

$\mathrm{H}_{013}$ : There is no significant association between awareness on Mahila Udyam Nidhi Scheme with sources of awareness among Women Entrepreneurs.

$\mathrm{H}_{014}$ : There is no significant association between awareness on Udyogini Yojana Scheme with sources of awareness among Women Entrepreneurs 
Table 4 Interrelationship between awareness on Stand Up India scheme with sources of awareness among Women Entrepreneurs.

\begin{tabular}{|c|c|c|c|c|c|}
\hline \multicolumn{6}{|c|}{ Sources of awareness about Various govt schemes * Stand Up India Crosstabulation } \\
\hline & & \multicolumn{3}{|c|}{ Stand Up India } & \multirow[b]{2}{*}{ Total } \\
\hline & & $\begin{array}{l}\text { Not at all } \\
\text { aware }\end{array}$ & $\begin{array}{c}\text { Moderately } \\
\text { Aware }\end{array}$ & $\begin{array}{c}\text { Extremely } \\
\text { Aware }\end{array}$ & \\
\hline \multirow{7}{*}{$\begin{array}{l}\text { Sources of awareness } \\
\text { about Various } \\
\text { Government schemes }\end{array}$} & Newspaper & 0 & 1 & 8 & 9 \\
\hline & Radio & 0 & 1 & 11 & 12 \\
\hline & Television & 2 & 4 & 13 & 19 \\
\hline & Pamphlets & 0 & 2 & 9 & 11 \\
\hline & Friends and family & 0 & 1 & 3 & 4 \\
\hline & $\begin{array}{l}\text { Social Media } \\
\text { Networking }\end{array}$ & 6 & 13 & 65 & 84 \\
\hline & Advertisement & 8 & 10 & 43 & 61 \\
\hline \multicolumn{2}{|l|}{ Total } & 16 & 32 & 152 & 200 \\
\hline
\end{tabular}

(Source: Primary)

\begin{tabular}{|l|c|c|c|}
\hline \multicolumn{4}{|c|}{ Chi-Square Tests } \\
\hline & Value & Df & $\begin{array}{c}\text { Asymptotic } \\
\text { Significance (2-sided) }\end{array}$ \\
\hline Pearson Chi-Square & $7.279^{\mathrm{a}}$ & 12 & 0.839 \\
\hline Likelihood Ratio & 9.850 & 12 & 0.629 \\
\hline Linear-by-Linear Association & 2.569 & 1 & 0.109 \\
\hline N of Valid Cases & 200 & & \\
\hline a. 12 cells (57.1\%) have expected count less than 5. The minimum expected count is .32. \\
\hline
\end{tabular}

(Source: Primary)

\begin{tabular}{|c|c|c|c|}
\hline \multicolumn{4}{|c|}{ Symmetric Measures } \\
\hline & & Value & $\begin{array}{l}\text { Approximate } \\
\text { Significance }\end{array}$ \\
\hline \multirow[t]{2}{*}{ Nominal by Nominal } & Phi & 0.191 & 0.839 \\
\hline & Cramer's V & 0.135 & 0.839 \\
\hline \multicolumn{2}{|c|}{$\mathrm{N}$ of Valid Cases } & 200 & \\
\hline
\end{tabular}

(Source: Primary)

Since the $p$ value is 0.839 which is greater than (>) 0.05 . Null hypothesis is accepted at $5 \%$ level of significance. Hence, There is no significant association between Stand Up India scheme with sources of awareness among Women Entrepreneurs.

Interpretation: The above table shows that it has low strength of association between awareness on Stand-Up India scheme and sources of awareness among Women Entrepreneurs. 
A Study on Women Entrepreneur's awareness about Government Schemes- Special Reference to Chennai District, Tamil Nadu

Table 5 Interrelationship between awareness on TREAD ( Trade Related Entrepreneurship Assistance and Development) scheme with sources of awareness among Women Entrepreneurs.

\begin{tabular}{|c|c|c|c|c|c|}
\hline \multicolumn{6}{|c|}{$\begin{array}{c}\text { Sources of awareness about Various Govt schemes * TREAD ( Trade Related Entrepreneurship } \\
\text { Assistance and Development) Crosstabulation }\end{array}$} \\
\hline & & \multicolumn{3}{|c|}{$\begin{array}{c}\text { TREAD ( Trade Related } \\
\text { Entrepreneurship Assistance and } \\
\text { Development) }\end{array}$} & \multirow[b]{2}{*}{ Total } \\
\hline & & $\begin{array}{c}\text { Not at all } \\
\text { aware }\end{array}$ & $\begin{array}{c}\text { Moderately } \\
\text { Aware }\end{array}$ & $\begin{array}{c}\text { Extremely } \\
\text { Aware }\end{array}$ & \\
\hline \multirow{7}{*}{$\begin{array}{l}\text { Sources of awareness } \\
\text { about Various } \\
\text { Government schemes }\end{array}$} & Newspaper & 6 & 2 & 1 & 9 \\
\hline & Radio & 9 & 3 & 0 & 12 \\
\hline & Television & 16 & 1 & 2 & 19 \\
\hline & Pamphlets & 10 & 1 & 0 & 11 \\
\hline & Friends and family & 4 & 0 & 0 & 4 \\
\hline & $\begin{array}{l}\text { Social Media } \\
\text { Networking }\end{array}$ & 60 & 22 & 2 & 84 \\
\hline & Advertisement & 48 & 10 & 3 & 61 \\
\hline \multicolumn{2}{|l|}{ Total } & 153 & 39 & 8 & 200 \\
\hline
\end{tabular}

(Source: Primary)

\begin{tabular}{|l|c|c|c|}
\hline \multicolumn{4}{|c|}{ Chi-Square Tests } \\
\hline & Value & df & $\begin{array}{c}\text { Asymptotic } \\
\text { Significance (2-sided) }\end{array}$ \\
\hline Pearson Chi-Square & $11.909^{\mathrm{a}}$ & 12 & 0.453 \\
\hline Likelihood Ratio & 13.591 & 12 & 0.328 \\
\hline Linear-by-Linear Association & .011 & 1 & 0.918 \\
\hline N of Valid Cases & 200 & & \\
\hline a. 13 cells (61.9\%) have expected count less than 5. The minimum expected count is .16. \\
\hline
\end{tabular}

(Source: Primary)

\begin{tabular}{|c|c|c|c|}
\hline \multicolumn{4}{|c|}{ Symmetric Measures } \\
\hline & & Value & $\begin{array}{c}\text { Approximate } \\
\text { Significance }\end{array}$ \\
\hline \multirow{2}{*}{ Nominal by Nominal } & Phi & 0.244 & 0.453 \\
\hline & Cramer's V & 0.173 & 0.453 \\
\hline
\end{tabular}

(Source: Primary)

Since the $p$ value is 0.453 which is greater than (>) 0.05 . Null hypothesis is accepted at $5 \%$ level of significance. Hence, There is no significant association awareness on TREAD (Trade Related Entrepreneurship Assistance and Development) scheme with sources of awareness among Women Entrepreneurs.

Interpretation: The above table shows that it has low strength of association between awareness on TREAD (Trade Related Entrepreneurship Assistance and Development) scheme with sources of awareness among Women Entrepreneurs. 
Table 6 Interrelationship between awareness on Bharatiya Mahila Bank scheme with sources of awareness among Women Entrepreneurs.

\begin{tabular}{|c|c|c|c|c|c|}
\hline \multicolumn{6}{|c|}{ Sources of awareness about Various govt schemes * Bharatiya Mahila Bank Crosstabulation } \\
\hline & & \multicolumn{3}{|c|}{ Bharatiya Mahila Bank } & \multirow[b]{2}{*}{ Total } \\
\hline & & $\begin{array}{l}\text { Not at all } \\
\text { aware }\end{array}$ & $\begin{array}{l}\text { Moderately } \\
\text { Aware }\end{array}$ & $\begin{array}{c}\text { Extremely } \\
\text { Aware }\end{array}$ & \\
\hline \multirow{7}{*}{$\begin{array}{l}\text { Sources of awareness } \\
\text { about Various govt } \\
\text { schemes }\end{array}$} & Newspaper & 5 & 1 & 3 & 9 \\
\hline & Radio & 2 & 0 & 10 & 12 \\
\hline & Television & 7 & 3 & 9 & 19 \\
\hline & Pamphlets & 1 & 2 & 8 & 11 \\
\hline & Friends and family & 0 & 0 & 4 & 4 \\
\hline & $\begin{array}{l}\text { Social Media } \\
\text { Networking }\end{array}$ & 27 & 5 & 52 & 84 \\
\hline & Advertisement & 20 & 4 & 37 & 61 \\
\hline \multicolumn{2}{|c|}{ Total } & 62 & 15 & 123 & 200 \\
\hline
\end{tabular}

(Source: Primary)

\begin{tabular}{|l|c|c|c|}
\hline \multicolumn{4}{|c|}{ Chi-Square Tests } \\
\hline & Value & Df & $\begin{array}{c}\text { Asymptotic } \\
\text { Significance (2-sided) }\end{array}$ \\
\hline Pearson Chi-Square & $14.815^{\mathrm{a}}$ & 12 & 0.252 \\
\hline Likelihood Ratio & 16.854 & 12 & 0.155 \\
\hline Linear-by-Linear Association & .070 & 1 & 0.791 \\
\hline N of Valid Cases & 200 & & \\
\hline
\end{tabular}

(Source: Primary)

\begin{tabular}{|c|c|c|c|}
\hline \multicolumn{3}{|c|}{ Symmetric Measures } \\
\hline \multicolumn{2}{|c|}{} & Value & $\begin{array}{c}\text { Approximate } \\
\text { Significance }\end{array}$ \\
\hline Nominal by Nominal & Phi & 0.272 & 0.252 \\
\cline { 2 - 4 } & Cramer's V & 0.192 & 0.252 \\
\hline \multicolumn{2}{|c|}{ N of Valid Cases } & 200 & \\
\hline
\end{tabular}

(Source: Primary)

Since the $p$ value is 0.252 which is greater than (>) 0.05 . Null hypothesis is accepted at $5 \%$ level of significance. Hence, There is no significant association between awareness on Bharatiya Mahila Bank scheme with sources of awareness among Women Entrepreneurs.

Interpretation: The above table shows that it has low strength of association between awareness on Bharatiya Mahila Bank scheme with sources of awareness among Women Entrepreneurs.

Table 7 Interrelationship between awareness on Akshaya Mahila Arthik Sahay Yojana (AMASY) scheme with sources of awareness among Women Entrepreneurs.

\begin{tabular}{|c|c|c|c|c|}
\hline \multicolumn{5}{|c|}{$\begin{array}{l}\text { Sources of awareness about Various govt schemes * Akshaya Mahila Arthik Sahay Yojana } \\
\text { (AMASY) Crosstabulation }\end{array}$} \\
\hline & \multicolumn{3}{|c|}{$\begin{array}{l}\text { Akshaya Mahila Arthik Sahay Yojana } \\
\text { (AMASY) }\end{array}$} & \multirow[b]{2}{*}{ Total } \\
\hline & $\begin{array}{c}\text { Not at all } \\
\text { aware }\end{array}$ & $\begin{array}{l}\text { Moderately } \\
\text { Aware }\end{array}$ & $\begin{array}{l}\text { Extremely } \\
\text { Aware }\end{array}$ & \\
\hline Newspaper & 5 & 2 & 2 & 9 \\
\hline Radio & 9 & 1 & 2 & 12 \\
\hline
\end{tabular}


A Study on Women Entrepreneur's awareness about Government Schemes- Special Reference to Chennai District, Tamil Nadu

\begin{tabular}{|l|l|c|c|c|c|}
\hline $\begin{array}{l}\text { Sources of awareness } \\
\text { about Various } \\
\text { Government schemes }\end{array}$ & Television & 13 & 3 & 3 & 19 \\
\cline { 2 - 6 } & Pamphlets & 9 & 1 & 1 & 11 \\
\cline { 2 - 6 } & Friends and family & 3 & 1 & 0 & 4 \\
\cline { 2 - 6 } & $\begin{array}{l}\text { Social Media } \\
\text { Networking }\end{array}$ & 61 & 13 & 10 & 84 \\
\cline { 2 - 6 } & Advertisement & 41 & 13 & 7 & 61 \\
\hline \multicolumn{2}{|l}{ Total } & 141 & 34 & 25 & 200 \\
\hline
\end{tabular}

(Source: Primary)

\begin{tabular}{|l|c|c|c|}
\hline \multicolumn{4}{|c|}{ Chi-Square Tests } \\
\hline & Value & Df & $\begin{array}{c}\text { Asymptotic } \\
\text { Significance (2-sided) }\end{array}$ \\
\hline Pearson Chi-Square & $4.407^{\mathrm{a}}$ & 12 & 0.975 \\
\hline Likelihood Ratio & 4.903 & 12 & 0.961 \\
\hline Linear-by-Linear Association & 0.242 & 1 & 0.623 \\
\hline N of Valid Cases & 200 & & \\
\hline a. 11 cells (52.4\%) have expected count less than 5. The minimum expected count is .50. \\
\hline
\end{tabular}

(Source: Primary)

\begin{tabular}{|c|c|c|c|}
\hline \multicolumn{4}{|c|}{ Symmetric Measures } \\
\hline & & Value & $\begin{array}{c}\text { Approximate } \\
\text { Significance }\end{array}$ \\
\hline \multirow{2}{*}{ Nominal by Nominal } & Phi & 0.148 & 0.975 \\
\hline & Cramer's V & 0.105 & 0.975 \\
\hline \multicolumn{2}{|c|}{$\mathrm{N}$ of Valid Cases } & 200 & \\
\hline
\end{tabular}

(Source: Primary)

Since the $p$ value is 0.975 which is greater than (>) 0.05 . Null hypothesis is accepted at $5 \%$ level of significance. Hence, There is no significant association between awareness on Akshaya Mahila Arthik Sahay Yojana (AMASY) scheme with sources of awareness among Women Entrepreneurs.

Interpretation: The above table shows that it has low strength of association between between awareness on Akshaya Mahila Arthik Sahay Yojana (AMASY) scheme with sources of awareness among Women Entrepreneurs.

Table 8 Interrelationship between awareness on Dena Shakti scheme with sources of awareness among Women Entrepreneurs.

\begin{tabular}{|c|c|c|c|c|c|}
\hline \multicolumn{6}{|c|}{ Sources of awareness about Various govt schemes * Dena Shakti Scheme Crosstabulation } \\
\hline & & \multicolumn{3}{|c|}{ Dena Shakti Scheme } & \multirow[b]{2}{*}{ Total } \\
\hline & & $\begin{array}{c}\text { Not at all } \\
\text { aware }\end{array}$ & $\begin{array}{c}\text { Moderately } \\
\text { Aware }\end{array}$ & $\begin{array}{c}\text { Extremely } \\
\text { Aware }\end{array}$ & \\
\hline \multirow{7}{*}{$\begin{array}{l}\text { Sources of awareness } \\
\text { about Various govt } \\
\text { schemes }\end{array}$} & Newspaper & 9 & 0 & 0 & 9 \\
\hline & Radio & 8 & 3 & 1 & 12 \\
\hline & Television & 18 & 1 & 0 & 19 \\
\hline & Pamphlets & 10 & 1 & 0 & 11 \\
\hline & Friends and family & 3 & 1 & 0 & 4 \\
\hline & Social Media Networking & 73 & 9 & 2 & 84 \\
\hline & \begin{tabular}{|l|} 
Advertisement \\
\end{tabular} & 56 & 2 & 3 & 61 \\
\hline Total & & 177 & 17 & 6 & 200 \\
\hline
\end{tabular}

(Source: Primary) 


\begin{tabular}{|l|c|c|c|}
\hline \multicolumn{4}{|c|}{ Chi-Square Tests } \\
\hline & Value & Df & $\begin{array}{c}\text { Asymptotic } \\
\text { Significance (2-sided) }\end{array}$ \\
\hline Pearson Chi-Square & $12.906^{\mathrm{a}}$ & 12 & 0.376 \\
\hline Likelihood Ratio & 13.358 & 12 & 0.344 \\
\hline Linear-by-Linear Association & .015 & 1 & 0.902 \\
\hline N of Valid Cases & 200 & & \\
\hline a. 13 cells (61.9\%) have expected count less than 5. The minimum expected count is .12. \\
\hline
\end{tabular}

(Source: Primary)

\begin{tabular}{|c|c|c|c|}
\hline \multicolumn{4}{|c|}{ Symmetric Measures } \\
\hline & & Value & $\begin{array}{c}\text { Approximate } \\
\text { Significance }\end{array}$ \\
\hline \multirow[t]{2}{*}{ Nominal by Nominal } & Phi & 0.254 & 0.376 \\
\hline & Cramer's V & 0.180 & 0.376 \\
\hline
\end{tabular}

(Source: Primary)

Since the p value is 0.376 which is greater than (>) 0.05 . Null hypothesis is accepted at $5 \%$ level of significance. Hence, There is no significant association between awareness on Dena Shakti Scheme with sources of awareness among Women Entrepreneurs.

Interpretation: The above table shows that it has low strength of association awareness on Dena Shakti Scheme with sources of awareness among Women Entrepreneurs.

Table 9 Interrelationship between between awareness on Stree Shakthi Package scheme with sources of awareness among Women Entrepreneurs.

\begin{tabular}{|c|c|c|c|c|c|}
\hline \multicolumn{6}{|c|}{ Sources of awareness about Various govt schemes * Stree Shakthi Package Crosstabulation } \\
\hline & & \multicolumn{3}{|c|}{ Stree Shakthi Package } & \multirow[b]{2}{*}{ Total } \\
\hline & & $\begin{array}{l}\text { Not at all } \\
\text { aware }\end{array}$ & $\begin{array}{c}\text { Moderately } \\
\text { Aware }\end{array}$ & $\begin{array}{c}\text { Extremely } \\
\text { Aware }\end{array}$ & \\
\hline \multirow{7}{*}{$\begin{array}{l}\text { Sources of awareness } \\
\text { about Various govt } \\
\text { schemes }\end{array}$} & Newspaper & 7 & 2 & 0 & 9 \\
\hline & Radio & 10 & 2 & 0 & 12 \\
\hline & Television & 12 & 4 & 3 & 19 \\
\hline & Pamphlets & 9 & 1 & 1 & 11 \\
\hline & Friends and family & 4 & 0 & 0 & 4 \\
\hline & $\begin{array}{l}\text { Social Media } \\
\text { Networking }\end{array}$ & 62 & 22 & 0 & 84 \\
\hline & Advertisement & 47 & 13 & 1 & 61 \\
\hline \multicolumn{2}{|c|}{ Total } & 151 & 44 & 5 & 200 \\
\hline
\end{tabular}

(Source: Primary)

\begin{tabular}{|l|c|c|c|}
\hline \multicolumn{4}{|c|}{ Chi-Square Tests } \\
\hline & Value & Df & $\begin{array}{c}\text { Asymptotic } \\
\text { Significance (2-sided) }\end{array}$ \\
\hline Pearson Chi-Square & $21.714^{\mathrm{a}}$ & 12 & 0.041 \\
\hline Likelihood Ratio & 17.354 & 12 & 0.137 \\
\hline Linear-by-Linear Association & .403 & 1 & 0.525 \\
\hline N of Valid Cases & 200 & & \\
\hline a. 13 cells (61.9\%) have expected count less than 5. The minimum expected count is .10. \\
\hline
\end{tabular}

(Source: Primary) 
A Study on Women Entrepreneur's awareness about Government Schemes- Special Reference to Chennai District, Tamil Nadu

\begin{tabular}{|c|c|c|c|}
\hline \multicolumn{4}{|c|}{ Symmetric Measures } \\
\hline Nominal by Nominal & Vhi & 0.329 & $\begin{array}{c}\text { Approximate } \\
\text { Significance }\end{array}$ \\
\hline & Cramer's V & 0.233 & 0.041 \\
\hline \multicolumn{2}{|c|}{ N of Valid Cases } & 200 & 0.041 \\
\hline
\end{tabular}

(Source: Primary)

Since the p value is 0.041 which is less than $(<) 0.05$. Null hypothesis is rejected at $5 \%$ level of significance. Hence, There is a significant association between awareness on Stree Shakthi Package scheme with sources of awareness among Women Entrepreneurs.

Interpretation: The above table shows that it has high strength of association awareness on Stree Shakthi Package scheme with sources of awareness among Women Entrepreneurs.

Table 10 Interrelationship between between awareness on Cent Kalyani scheme with sources of awareness among Women Entrepreneurs.

\begin{tabular}{|c|c|c|c|c|c|}
\hline \multicolumn{6}{|c|}{ Sources of awareness about Various govt schemes * Cent Kalyani Scheme Crosstabulation } \\
\hline & & \multicolumn{3}{|c|}{ Cent Kalyani Scheme } & \multirow[b]{2}{*}{ Total } \\
\hline & & $\begin{array}{c}\text { Not at all } \\
\text { aware }\end{array}$ & $\begin{array}{c}\text { Moderately } \\
\text { Aware }\end{array}$ & $\begin{array}{c}\text { Extremely } \\
\text { Aware }\end{array}$ & \\
\hline \multirow{7}{*}{$\begin{array}{l}\text { Sources of awareness } \\
\text { about Various } \\
\text { Government schemes }\end{array}$} & Newspaper & 7 & 2 & 0 & 9 \\
\hline & Radio & 9 & 3 & 0 & 12 \\
\hline & Television & 19 & 0 & 0 & 19 \\
\hline & Pamphlets & 8 & 2 & 1 & 11 \\
\hline & Friends and family & 4 & 0 & 0 & 4 \\
\hline & $\begin{array}{l}\text { Social Media } \\
\text { Networking }\end{array}$ & 71 & 11 & 2 & 84 \\
\hline & Advertisement & 50 & 9 & 2 & 61 \\
\hline \multicolumn{2}{|c|}{ Total } & 168 & 27 & 5 & 200 \\
\hline
\end{tabular}

(Source: Primary)

\begin{tabular}{|l|c|c|c|}
\hline \multicolumn{4}{|c|}{ Chi-Square Tests } \\
\hline & Value & Df & $\begin{array}{c}\text { Asymptotic } \\
\text { Significance (2-sided) }\end{array}$ \\
\hline Pearson Chi-Square & $9.269^{\mathrm{a}}$ & 12 & 0.680 \\
\hline Likelihood Ratio & 12.313 & 12 & 0.421 \\
\hline Linear-by-Linear Association & .144 & 1 & 0.705 \\
\hline N of Valid Cases & 200 & & \\
\hline a. 13 cells (61.9\%) have expected count less than 5. The minimum expected count is .10. \\
\hline
\end{tabular}

(Source: Primary)

\begin{tabular}{|c|c|c|c|}
\hline \multicolumn{3}{|c|}{ Symmetric Measures } \\
\hline \multirow{2}{*}{} & Value & $\begin{array}{c}\text { Approximate } \\
\text { Significance }\end{array}$ \\
\hline Nominal by Nominal & Phi & 0.215 & 0.680 \\
\hline & Cramer's V & 0.152 & 0.680 \\
\hline \multicolumn{2}{|c|}{ N of Valid Cases } & 200 & \\
\hline
\end{tabular}

(Source: Primary) 
Since the $\mathrm{p}$ value is 0.680 which is greater than (>) 0.05 . Null hypothesis is accepted at $5 \%$ level of significance. Hence, There is a no significant association between awareness on Cent Kalyani scheme with sources of awareness among Women Entrepreneurs.

Interpretation: The above table shows that it has low strength of association awareness on Cent Kalyani scheme with sources of awareness among Women Entrepreneurs.

Table 11 Interrelationship between between awareness on Can Mahila scheme with sources of awareness among Women Entrepreneurs.

\begin{tabular}{|c|c|c|c|c|c|}
\hline \multicolumn{6}{|c|}{ Sources of awareness about Various govt schemes * Can Mahila Scheme Crosstabulation } \\
\hline & & \multicolumn{3}{|c|}{ Can Mahila Scheme } & \multirow[b]{2}{*}{ Total } \\
\hline & & $\begin{array}{c}\text { Not at all } \\
\text { aware }\end{array}$ & $\begin{array}{c}\text { Moderately } \\
\text { Aware }\end{array}$ & $\begin{array}{c}\text { Extremely } \\
\text { Aware }\end{array}$ & \\
\hline \multirow{7}{*}{$\begin{array}{l}\text { Sources of awareness } \\
\text { about Various govt } \\
\text { schemes }\end{array}$} & Newspaper & 9 & 0 & 0 & 9 \\
\hline & Radio & 9 & 1 & 2 & 12 \\
\hline & Television & 15 & 3 & 1 & 19 \\
\hline & Pamphlets & 8 & 2 & 1 & 11 \\
\hline & Friends and family & 4 & 0 & 0 & 4 \\
\hline & $\begin{array}{l}\text { Social Media } \\
\text { Networking }\end{array}$ & 72 & 10 & 2 & 84 \\
\hline & Advertisement & 55 & 5 & 1 & 61 \\
\hline \multicolumn{2}{|c|}{ Total } & 172 & 21 & 7 & 200 \\
\hline
\end{tabular}

(Source: Primary)

\begin{tabular}{|l|l|l|l|}
\hline \multicolumn{4}{|c|}{ Chi-Square Tests } \\
\hline & \multicolumn{1}{|c|}{ Value } & \multicolumn{1}{c|}{ df } & $\begin{array}{c}\text { Asymptotic } \\
\text { Significance (2-sided) }\end{array}$ \\
\hline Pearson Chi-Square & $12.387^{\mathrm{a}}$ & 12 & 0.415 \\
\hline Likelihood Ratio & 11.057 & 12 & 0.524 \\
\hline Linear-by-Linear Association & 1.854 & 1 & 0.173 \\
\hline N of Valid Cases & 200 & & \\
\hline a. 13 cells (61.9\%) have expected count less than 5. The minimum expected count is .14. \\
\hline
\end{tabular}

(Source: Primary)

\begin{tabular}{|c|c|c|c|}
\hline \multicolumn{4}{|c|}{ Symmetric Measures } \\
\hline & & Value & $\begin{array}{c}\text { Approximate } \\
\text { Significance }\end{array}$ \\
\hline \multirow[t]{2}{*}{ Nominal by Nominal } & Phi & 0.249 & 0.415 \\
\hline & Cramer's V & 0.176 & 0.415 \\
\hline \multicolumn{2}{|c|}{$\mathrm{N}$ of Valid Cases } & 200 & \\
\hline
\end{tabular}

(Source: Primary)

Since the p value is 0.415 which is greater than (>) 0.05 . Null hypothesis is accepted at $5 \%$ level of significance. Hence, There is a no significant association between awareness on Can Mahila scheme with sources of awareness among Women Entrepreneurs.

Interpretation: The above table shows that it has low strength of association awareness on Can Mahila scheme with sources of awareness among Women Entrepreneurs. 
A Study on Women Entrepreneur's awareness about Government Schemes- Special Reference to Chennai District, Tamil Nadu

Table 12 Interrelationship between between awareness on Rashtriya Mahila Kosh scheme with sources of awareness among Women Entrepreneurs.

\begin{tabular}{|c|c|c|c|c|c|}
\hline \multicolumn{6}{|c|}{ Sources of awareness about Various govt schemes * Rashtriya Mahila Kosh Crosstabulation } \\
\hline & & $\mathbf{R a}$ & triya Mahila & osh & \multirow[b]{2}{*}{ Total } \\
\hline & & $\begin{array}{l}\text { Not at all } \\
\text { aware }\end{array}$ & $\begin{array}{l}\text { Moderately } \\
\text { Aware }\end{array}$ & $\begin{array}{c}\text { Extremely } \\
\text { Aware }\end{array}$ & \\
\hline \multirow{7}{*}{$\begin{array}{l}\text { Sources of awareness } \\
\text { about Various govt } \\
\text { schemes }\end{array}$} & Newspaper & 8 & 1 & 0 & 9 \\
\hline & Radio & 10 & 2 & 0 & 12 \\
\hline & Television & 16 & 2 & 1 & 19 \\
\hline & Pamphlets & 9 & 2 & 0 & 11 \\
\hline & Friends and family & 3 & 0 & 1 & 4 \\
\hline & $\begin{array}{l}\text { Social Media } \\
\text { Networking }\end{array}$ & 74 & 6 & 4 & 84 \\
\hline & Advertisement & 54 & 5 & 2 & 61 \\
\hline \multicolumn{2}{|c|}{ Total } & 174 & 18 & 8 & 200 \\
\hline
\end{tabular}

(Source: Primary)

\begin{tabular}{|l|c|c|c|}
\hline \multicolumn{4}{|c|}{ Chi-Square Tests } \\
\hline & Value & Df & $\begin{array}{c}\text { Asymptotic } \\
\text { Significance (2-sided) }\end{array}$ \\
\hline Pearson Chi-Square & $8.768^{\mathrm{a}}$ & 12 & 0.723 \\
\hline Likelihood Ratio & 7.602 & 12 & 0.815 \\
\hline Linear-by-Linear Association & .043 & 1 & 0.836 \\
\hline N of Valid Cases & 200 & & \\
\hline a. 13 cells (61.9\%) have expected count less than 5. The minimum expected count is .16. \\
\hline
\end{tabular}

(Source: Primary)

\begin{tabular}{|l|c|c|c|}
\hline \multicolumn{4}{|c|}{ Symmetric Measures } \\
\hline \multirow{2}{|c|}{} & Value & $\begin{array}{c}\text { Approximate } \\
\text { Significance }\end{array}$ \\
\hline Nominal by Nominal & Phi & 0.209 & 0.723 \\
\cline { 2 - 4 } & Cramer's V & 0.148 & 0.723 \\
\hline \multicolumn{2}{|c|}{ N of Valid Cases } & 200 & \\
\hline
\end{tabular}

(Source: Primary)

Since the p value is 0.723 which is greater than (>) 0.05 . Null hypothesis is accepted at $5 \%$ level of significance. Hence, There is a no significant association between awareness on Rashtriya Mahila Kosh scheme with sources of awareness among Women Entrepreneurs.

Interpretation: The above table shows that it has low strength of association awareness on Rashtriya Mahila Kosh scheme with sources of awareness among Women Entrepreneurs. 
Table 13 Interrelationship between between awareness on Pradhan Mantri Mudra Yojna (PMMY)scheme with sources of awareness among Women Entrepreneurs.

\begin{tabular}{|c|c|c|c|c|c|}
\hline \multicolumn{6}{|c|}{$\begin{array}{c}\text { Sources of awareness about Various govt schemes * Pradhan Mantri Mudra Yojna (PMMY) } \\
\text { Crosstabulation }\end{array}$} \\
\hline & & \multicolumn{3}{|c|}{ Pradhan Mantri Mudra Yojna (PMMY) } & \multirow[b]{2}{*}{ Total } \\
\hline & & $\begin{array}{l}\text { Not at all } \\
\text { aware }\end{array}$ & $\begin{array}{l}\text { Moderately } \\
\text { Aware }\end{array}$ & $\begin{array}{c}\text { Extremely } \\
\text { Aware }\end{array}$ & \\
\hline \multirow{7}{*}{$\begin{array}{l}\text { Sources of awareness } \\
\text { about Various govt } \\
\text { schemes }\end{array}$} & Newspaper & 7 & 2 & 0 & 9 \\
\hline & Radio & 8 & 2 & 2 & 12 \\
\hline & Television & 17 & 1 & 1 & 19 \\
\hline & Pamphlets & 11 & 0 & 0 & 11 \\
\hline & Friends and family & 4 & 0 & 0 & 4 \\
\hline & $\begin{array}{l}\text { Social Media } \\
\text { Networking }\end{array}$ & 75 & 6 & 3 & 84 \\
\hline & Advertisement & 57 & 4 & 0 & 61 \\
\hline \multicolumn{2}{|c|}{ Total } & 179 & 15 & 6 & 200 \\
\hline
\end{tabular}

(Source: Primary)

\begin{tabular}{|l|c|c|c|}
\hline \multicolumn{4}{|c|}{ Chi-Square Tests } \\
\hline & Value & Df & $\begin{array}{c}\text { Asymptotic } \\
\text { Significance (2-sided) }\end{array}$ \\
\hline Pearson Chi-Square & $16.849^{\mathrm{a}}$ & 12 & 0.155 \\
\hline Likelihood Ratio & 15.395 & 12 & 0.221 \\
\hline Linear-by-Linear Association & 4.917 & 1 & 0.027 \\
\hline N of Valid Cases & 200 & & \\
\hline a. 14 cells (66.7\%) have expected count less than 5. The minimum expected count is .12. \\
\hline
\end{tabular}

(Source: Primary)

\begin{tabular}{|c|c|c|c|}
\hline \multicolumn{3}{|c|}{ Symmetric Measures } \\
\hline \multicolumn{2}{|c|}{} & Value & $\begin{array}{c}\text { Approximate } \\
\text { Significance }\end{array}$ \\
\hline Nominal by Nominal & Phi & 0.290 & 0.155 \\
\hline & Cramer's V & 0.205 & 0.155 \\
\hline \multicolumn{2}{|c|}{ N of Valid Cases } & 200 & \\
\hline
\end{tabular}

(Source: Primary)

Since the p value is 0.155 which is greater than (>) 0.05 . Null hypothesis is accepted at $5 \%$ level of significance. Hence, There is a no significant association between awareness on Pradhan Mantri Mudra Yojna (PMMY) scheme with sources of awareness among Women Entrepreneurs.

Interpretation: The above table shows that it has moderate strength of association awareness on Pradhan Mantri Mudra Yojna (PMMY) scheme with sources of awareness among Women Entrepreneurs. 
A Study on Women Entrepreneur's awareness about Government Schemes- Special Reference to Chennai District, Tamil Nadu

Table 14 Interrelationship between between awareness on Indira Mahila Yojana scheme with sources of awareness among Women Entrepreneurs.

\begin{tabular}{|c|c|c|c|c|c|}
\hline \multicolumn{6}{|c|}{ Sources of awareness about Various govt schemes * Indira Mahila Yojana Crosstabulation } \\
\hline & & \multicolumn{3}{|c|}{$\begin{array}{l}\text { Indira Mahila Yojana } \\
\end{array}$} & \multirow[b]{2}{*}{ Total } \\
\hline & & $\begin{array}{l}\text { Not at all } \\
\text { aware }\end{array}$ & $\begin{array}{c}\text { Moderately } \\
\text { Aware }\end{array}$ & $\begin{array}{c}\text { Extremely } \\
\text { Aware }\end{array}$ & \\
\hline \multirow{7}{*}{$\begin{array}{l}\text { Sources of awareness } \\
\text { about Various govt } \\
\text { schemes }\end{array}$} & Newspaper & 9 & 0 & 0 & 9 \\
\hline & Radio & 11 & 1 & 0 & 12 \\
\hline & Television & 18 & 1 & 0 & 19 \\
\hline & Pamphlets & 11 & 0 & 0 & 11 \\
\hline & Friends and family & 4 & 0 & 0 & 4 \\
\hline & \begin{tabular}{|l|} 
Social Media \\
Networking \\
\end{tabular} & 76 & 6 & 2 & 84 \\
\hline & Advertisement & 58 & 2 & 1 & 61 \\
\hline \multicolumn{2}{|c|}{ Total } & 187 & 10 & 3 & 200 \\
\hline
\end{tabular}

(Source: Primary)

\begin{tabular}{|l|c|c|c|}
\hline \multicolumn{4}{|c|}{ Chi-Square Tests } \\
\hline & Value & Df & $\begin{array}{c}\text { Asymptotic } \\
\text { Significance (2-sided) }\end{array}$ \\
\hline Pearson Chi-Square & $4.084^{\mathrm{a}}$ & 12 & 0.982 \\
\hline Likelihood Ratio & 5.955 & 12 & 0.918 \\
\hline Linear-by-Linear Association & .585 & 1 & 0.444 \\
\hline N of Valid Cases & 200 & & \\
\hline a. 15 cells (71.4\%) have expected count less than 5. The minimum expected count is .06. \\
\hline
\end{tabular}

(Source: Primary)

\begin{tabular}{|c|c|c|c|}
\hline \multicolumn{4}{|c|}{ Symmetric Measures } \\
\hline \multirow{3}{*}{} & Value & $\begin{array}{c}\text { Approximate } \\
\text { Significance }\end{array}$ \\
\hline Nominal by Nominal & Phi & 0.143 & 0.982 \\
\hline & Cramer's V & 0.101 & .982 \\
\hline N of Valid Cases & 200 & \\
\hline
\end{tabular}

(Source: Primary)

Since the $p$ value is 0.982 which is greater than (>) 0.05 . Null hypothesis is accepted at $5 \%$ level of significance. Hence, There is a no significant association between awareness on Indira Mahila Yojana scheme with sources of awareness among Women Entrepreneurs.

Interpretation: The above table shows that it has low strength of association awareness on Indira Mahila Yojana scheme with sources of awareness among Women Entrepreneurs. 
Table 15 Interrelationship between between awareness on Shringaar and Annapurna Scheme from Bhartiya Mahila Bank scheme with sources of awareness among Women Entrepreneurs.

\begin{tabular}{|c|c|c|c|c|c|}
\hline \multicolumn{6}{|c|}{$\begin{array}{c}\text { Sources of awareness about Various govt schemes * Shringaar and Annapurna Scheme from } \\
\text { Bhartiya Mahila Bank Crosstabulation }\end{array}$} \\
\hline & & \multicolumn{3}{|c|}{$\begin{array}{l}\text { Shringaar and Annapurna Scheme from } \\
\text { Bhartiya Mahila Bank }\end{array}$} & \multirow[b]{2}{*}{ Total } \\
\hline & & $\begin{array}{l}\text { Not at all } \\
\text { aware }\end{array}$ & $\begin{array}{l}\text { Moderately } \\
\text { Aware }\end{array}$ & $\begin{array}{l}\text { Extremely } \\
\text { Aware }\end{array}$ & \\
\hline \multirow{7}{*}{$\begin{array}{l}\text { Sources of awareness } \\
\text { about Various } \\
\text { Government schemes }\end{array}$} & Newspaper & 8 & 1 & 0 & 9 \\
\hline & Radio & 10 & 2 & 0 & 12 \\
\hline & Television & 16 & 2 & 1 & 19 \\
\hline & Pamphlets & 8 & 1 & 2 & 11 \\
\hline & Friends and family & 4 & 0 & 0 & 4 \\
\hline & $\begin{array}{l}\text { Social Media } \\
\text { Networking }\end{array}$ & 71 & 7 & 6 & 84 \\
\hline & Advertisement & 57 & 4 & 0 & 61 \\
\hline \multicolumn{2}{|c|}{ Total } & 174 & 17 & 9 & 200 \\
\hline
\end{tabular}

(Source: Primary)

\begin{tabular}{|l|c|c|c|}
\hline \multicolumn{4}{|c|}{ Chi-Square Tests } \\
\hline & Value & Df & $\begin{array}{c}\text { Asymptotic } \\
\text { Significance (2-sided) }\end{array}$ \\
\hline Pearson Chi-Square & $12.223^{\mathrm{a}}$ & 12 & 0.428 \\
\hline Likelihood Ratio & 14.039 & 12 & 0.298 \\
\hline Linear-by-Linear Association & .796 & 1 & 0.372 \\
\hline N of Valid Cases & 200 & & \\
\hline a. 13 cells (61.9\%) have expected count less than 5. The minimum expected count is .18. \\
\hline
\end{tabular}

(Source: Primary)

\begin{tabular}{|c|c|c|c|}
\hline \multicolumn{4}{|c|}{ Symmetric Measures } \\
\hline & & Value & $\begin{array}{l}\text { Approximate } \\
\text { Significance }\end{array}$ \\
\hline \multirow[t]{2}{*}{ Nominal by Nominal } & Phi & 0.247 & 0.428 \\
\hline & Cramer's V & 0.175 & 0.428 \\
\hline \multicolumn{2}{|c|}{$\mathrm{N}$ of Valid Cases } & 200 & \\
\hline
\end{tabular}

(Source: Primary)

Since the p value is 0.482 which is greater than (>) 0.05 . Null hypothesis is accepted at $5 \%$ level of significance. Hence, There is a no significant association between awareness on Shringaar and Annapurna Scheme from Bhartiya Mahila Bank scheme with sources of awareness among Women Entrepreneurs.

Interpretation: The above table shows that it has low strength of association awareness on Shringaar and Annapurna Scheme from Bhartiya Mahila Bank scheme with sources of awareness among Women Entrepreneurs. 
A Study on Women Entrepreneur's awareness about Government Schemes- Special Reference to Chennai District, Tamil Nadu

Table 16 Interrelationship between between awareness on Mahila Udyam Nidhi scheme with sources of awareness among Women Entrepreneurs.

\begin{tabular}{|c|c|c|c|c|c|}
\hline \multicolumn{6}{|c|}{$\begin{array}{c}\text { Sources of awareness about Various govt schemes * Mahila Udyam Nidhi Scheme } \\
\text { Crosstabulation }\end{array}$} \\
\hline & & \multicolumn{3}{|c|}{ Mahila Udyam Nidhi Scheme } & \multirow[b]{2}{*}{ Total } \\
\hline & & $\begin{array}{l}\text { Not at all } \\
\text { aware }\end{array}$ & $\begin{array}{l}\text { Moderately } \\
\text { Aware }\end{array}$ & $\begin{array}{l}\text { Extremely } \\
\text { Aware }\end{array}$ & \\
\hline \multirow{7}{*}{$\begin{array}{l}\text { Sources of awareness } \\
\text { about Various } \\
\text { Government schemes }\end{array}$} & Newspaper & 9 & 0 & 0 & 9 \\
\hline & Radio & 10 & 1 & 1 & 12 \\
\hline & Television & 17 & 2 & 0 & 19 \\
\hline & Pamphlets & 8 & 1 & 2 & 11 \\
\hline & Friends and family & 4 & 0 & 0 & 4 \\
\hline & $\begin{array}{l}\text { Social Media } \\
\text { Networking }\end{array}$ & 73 & 8 & 3 & 84 \\
\hline & Advertisement & 56 & 3 & 2 & 61 \\
\hline & tal & 177 & 15 & 8 & 200 \\
\hline
\end{tabular}

(Source: Primary)

\begin{tabular}{|l|c|c|c|}
\hline \multicolumn{4}{|c|}{ Chi-Square Tests } \\
\hline & Value & Df & $\begin{array}{c}\text { Asymptotic } \\
\text { Significance (2-sided) }\end{array}$ \\
\hline Pearson Chi-Square & $10.389^{\mathrm{a}}$ & 12 & 0.582 \\
\hline Likelihood Ratio & 9.944 & 12 & 0.621 \\
\hline Linear-by-Linear Association & .075 & 1 & 0.784 \\
\hline N of Valid Cases & 200 & & \\
\hline a. 14 cells (66.7\%) have expected count less than 5. The minimum expected count is .16. \\
\hline
\end{tabular}

(Source: Primary)

\begin{tabular}{|c|c|c|c|}
\hline \multicolumn{4}{|c|}{ Symmetric Measures } \\
\hline \multirow{2}{*}{ Nominal by Nominal } & Value & Approximate Significance \\
\hline & Phi & 0.228 & 0.582 \\
\cline { 2 - 4 } & Cramer's V & 0.161 & 0.582 \\
\hline \multicolumn{2}{|c|}{ N of Valid Cases } & 200 & \\
\hline
\end{tabular}

(Source: Primary)

Since the p value is 0.582 which is greater than (>) 0.05 . Null hypothesis is accepted at $5 \%$ level of significance. Hence, There is a no significant association between awareness on Mahila Udyam Nidhi scheme with sources of awareness among Women Entrepreneurs.

Interpretation: The above table shows that it has low strength of association awareness on Mahila Udyam Nidhi scheme with sources of awareness among Women Entrepreneurs. 
Table 17 Interrelationship between between awareness on Udyogini Yojana scheme with sources of awareness among Women Entrepreneurs.

\begin{tabular}{|c|c|c|c|c|c|}
\hline \multicolumn{6}{|c|}{ Sources of awareness about Various govt schemes * Udyogini Yojana Crosstabulation } \\
\hline & & \multicolumn{3}{|c|}{ Udyogini Yojana } & \multirow[b]{2}{*}{ Total } \\
\hline & & $\begin{array}{c}\text { Not at all } \\
\text { aware }\end{array}$ & $\begin{array}{l}\text { Moderately } \\
\text { Aware }\end{array}$ & $\begin{array}{c}\text { Extremely } \\
\text { Aware }\end{array}$ & \\
\hline \multirow{7}{*}{$\begin{array}{l}\text { Sources of awareness } \\
\text { about Various } \\
\text { Government schemes }\end{array}$} & Newspaper & 9 & 0 & 0 & 9 \\
\hline & Radio & 10 & 1 & 1 & 12 \\
\hline & Television & 15 & 4 & 0 & 19 \\
\hline & Pamphlets & 10 & 1 & 0 & 11 \\
\hline & Friends and family & 4 & 0 & 0 & 4 \\
\hline & $\begin{array}{l}\text { Social Media } \\
\text { Networking }\end{array}$ & 76 & 8 & 0 & 84 \\
\hline & Advertisement & 52 & 8 & 1 & 61 \\
\hline \multicolumn{2}{|c|}{ Total } & 176 & 22 & 2 & 200 \\
\hline
\end{tabular}

(Source: Primary)

\begin{tabular}{|l|c|c|c|}
\hline \multicolumn{4}{|c|}{ Chi-Square Tests } \\
\hline & Value & df & $\begin{array}{c}\text { Asymptotic } \\
\text { Significance (2-sided) }\end{array}$ \\
\hline Pearson Chi-Square & $12.218^{\mathrm{a}}$ & 12 & 0.428 \\
\hline Likelihood Ratio & 10.532 & 12 & 0.569 \\
\hline Linear-by-Linear Association & .013 & 1 & 0.909 \\
\hline N of Valid Cases & 200 & & \\
\hline a. 13 cells (61.9\%) have expected count less than 5. The minimum expected count is .04. \\
\hline
\end{tabular}

(Source: Primary)

\begin{tabular}{|c|c|c|c|}
\hline \multicolumn{3}{|c|}{ Symmetric Measures } \\
\hline \multirow{2}{|c|}{} & Value & $\begin{array}{c}\text { Approximate } \\
\text { Significance }\end{array}$ \\
\hline Nominal by Nominal & Phi & 0.247 & 0.428 \\
\cline { 2 - 4 } & Cramer's V & 0.175 & 0.428 \\
\hline \multicolumn{2}{|c|}{ N of Valid Cases } & 200 & \\
\hline
\end{tabular}

(Source: Primary)

Since the $p$ value is 0.428 which is greater than (>) 0.05 . Null hypothesis is accepted at $5 \%$ level of significance. Hence, There is a no significant association between awareness on Udyogini Yojana scheme with sources of awareness among Women Entrepreneurs.

Interpretation: The above table shows that it has low strength of association awareness on Udyogini Yojana scheme with sources of awareness among Women Entrepreneurs.

\subsection{Interrelationship between Number of Training programmes taken, training programme attended and changes happened after attending training programmes}

\section{Hypothesis}

$\mathrm{H}_{0}$ : There is no significant variation of changes gained by Women Entrepreneurs after attending training programmes.

$\mathrm{H}_{1}$ : There is a significant variation of changes gained by Women Entrepreneurs after attending training programmes 
A Study on Women Entrepreneur's awareness about Government Schemes- Special Reference to Chennai District, Tamil Nadu

Dependent variable : Change faced after attending training programmes

Independent variable (Fixed factor): Training Programme attended (Covariate variable): Number of training programmes taken

\begin{tabular}{|c|c|c|c|}
\hline \multicolumn{4}{|c|}{ Between-Subjects Factors } \\
\hline & & Value Label & $\mathbf{N}$ \\
\hline \multirow{7}{*}{$\begin{array}{l}\text { Training programmes attended by the } \\
\text { respondents }\end{array}$} & 1.00 & Start-Up India & 95 \\
\hline & 2.00 & $\begin{array}{l}\text { Atal Innovation Mission } \\
\text { (AIM) }\end{array}$ & 25 \\
\hline & 3.00 & $\begin{array}{l}\text { Make in India Skill India } \\
\text { - Kaushal Bharat Kushal } \\
\text { Bharat }\end{array}$ & 20 \\
\hline & 4.00 & $\begin{array}{l}\text { National Skill } \\
\text { Development Skill }\end{array}$ & 16 \\
\hline & 5.00 & $\begin{array}{l}\text { The Federation of Indian } \\
\text { Women Entrepreneurs } \\
\text { (FIWE) }\end{array}$ & 15 \\
\hline & 6.00 & $\begin{array}{l}\text { Technology Development } \\
\text { and Utilization } \\
\text { Programme for Women } \\
\text { (TDUPW) }\end{array}$ & 14 \\
\hline & 7.00 & $\begin{array}{l}\text { Support to Training and } \\
\text { Employment Programme } \\
\text { for Women (STEP) }\end{array}$ & 15 \\
\hline
\end{tabular}

(Source: Primary)

\begin{tabular}{|l|l|c|c|c|c|}
\hline \multicolumn{7}{|c|}{ Tests of Between-Subjects Effects } \\
\hline \multicolumn{1}{|c|}{ Source } & $\begin{array}{c}\text { Type III Sum of } \\
\text { Squares }\end{array}$ & Df & Mean Square & F & Sig. \\
\hline Corrected Model & $88.502^{\mathrm{a}}$ & 7 & 12.643 & 3.297 & 0.002 \\
\hline Intercept & 561.662 & 1 & 561.662 & 146.445 & 0.000 \\
\hline Training programme & 86.467 & 6 & 14.411 & 3.758 & 0.001 \\
\hline Number of Training & 0.816 & 1 & 0.816 & 0.213 & 0.645 \\
\hline Error & 736.378 & 192 & 3.835 & & \\
\hline Total & 3504.000 & 200 & & & \\
\hline Corrected Total & 824.880 & 199 & & & \\
\hline a. R Squared $=.107$ (Adjusted R Squared =.075)
\end{tabular}

(Source: Primary)

Since, $\mathrm{P}$ value of number of training taken is 0.645 is greater than $(>) 0.05$, Null Hypothesis is accepted. There is no significant variation of changes gained by Women Entrepreneurs after attending training programmes. However, Fixed factor variable i.e. training programme is 0.001 .

There is a impact of training programme taken with changes gained after taking training programmes. Hence, Training programme is beneficial for women entrepreneurs.

Number of times training taken by Women Entrepreneurs has no influence on changes gained by women entrepreneurs but training programme has a significant influence towards benefits gained by women entrepreneurs after attending training programme. 


\section{FINDINGS}

1. There is a low level strength of significant association between sources of Awareness towards awareness on Stand Up India scheme.

2. There is a low level strength of significant association between sources of Awareness towards awareness on TREAD (Trade Related Entrepreneurship Assistance and Development) scheme

3. There is a low level strength of significant association between sources of Awareness towards awareness on Bharatiya Mahila Bank scheme

4. There is a low level strength of significant association between sources of Awareness towards awareness on Akshaya Mahila Arthik Sahay Yojana (AMASY) scheme.

5. There is a high strength level of significant association between sources of Awareness towards awareness on Dena Shakti Scheme.

6. There is a low strength level of significant association between sources of Awareness towards awareness on Stree Shakthi Package scheme

7. There is a low strength level of significant association between sources of Awareness towards awareness on Cent Kalyani Scheme scheme

8. There is a low strength level of significant association between sources of Awareness towards awareness on Can Mahila Scheme scheme

9. There is a low strength level of significant association between sources of Awareness towards awareness on Rashtriya Mahila Kosh scheme

10. There is a moderate strength level of significant association between sources of Awareness towards awareness on Pradhan Mantri MUDRA Yojna (PMMY)scheme

11. There is a low level of significant association between sources of Awareness towards awareness on Indira Mahila Yojana scheme

12. There is a low level of significant association between sources of Awareness towards awareness on Shringaar and Annapurna Scheme from Bhartiya Mahila Bank scheme

13. There is a low level of significant association between sources of Awareness towards awareness on Mahila Udyam Nidhi Scheme.

14. There is a low level of significant association between sources of Awareness towards awareness on Udyogini Yojana scheme

Women Entrepreneurs have low strength significance level of awareness towards all schemes except Stree Shakthi Package scheme.

There is strong relationship between investment made by the respondents and sources of finance for initial investment in business by the respondents.

The hierarchical mean rank for starting their business among Women Entrepreneurs is providing employment opportunity to others (4.64), self-status function (4.95), needed the money (5.06), to become expert (5.10), to be creative and try to do something new (5.31), flexibility in work (5.65), to gain business knowledge (5.97), to make profit and wealth (6.50), and to continue family business (6.52).

Number of times training taken has no influence on changes gained by women entrepreneurs but training programme has a significant influence on Women Entrepreneurs towards changes experienced by them. Majority of Women Entrepreneurs (47.5\%) has attended Start-Up India programme. The changes experienced, after attending training programme are easy assessment of business performance, more opportunities of networking, novel ways of innovation, helps in identifying strength and weakness of business, developing skills, reduction of stress in managing business and inspired to work better. 
A Study on Women Entrepreneur's awareness about Government Schemes- Special Reference to Chennai District, Tamil Nadu

\section{SUGGESTIONS}

- Awareness has to be created as there is a lack of awareness among Women Entrepreneurs towards various Women Entrepreneurial schemes. This can be done by organizing entrepreneurial awareness programmes, interaction with successful entrepreneurs, film slides, T.V interviews, panel discussions, seminars, workshops and symposiums to develop Entrepreneurship among Women.

- Adequate training has to be given to Women Entrepreneurs, as it is very essential for development of Women Entrepreneurs. Training has to be given on focus of planning, organizing, directing, controlling of production, marketing and finance.

- Entrepreneurial education should be added from Higher Secondary level and starting Vocational courses on entrepreneurship in colleges and Universities. It will be helpful for building confidence among potential Entrepreneurs at their early stage.

- Technological training programmes has to be provided for Women Entrepreneurs in recent development in production and marketing related activities. This can be done by conducting training programmes through various institution.

- Good quality infrastructural facilities has to be given to Women Entrepreneurs. Infrastructural facilities like water supply, electricity, technology, building, transportation, markets and banks needed to be strengthened for development of Entrepreneurship and smooth movement of entrepreneurial activities.

- Family members needs to encourage women their family to undertake Entrepreneurial activities by providing essential requirements like financial, marketing, labour and family support.

All the above given suggestions encourages women in Entrepreneurial activities and empowers socially and economically.

\section{CONCLUSION}

Today, Women are said to be in a better position by increasing participation in the field of entrepreneurship. Government of India and State Government of Tamil Nadu has implemented several schemes for Women like Stand Up India, TREAD, Bharatiya Mahila Bank, AMASY, Dena Shakti, Stree Shakthi Package, Cent Kalyani Scheme, Cent Mahila Scheme, etc.. The Objective of these scheme is to encourage and develop Women in Entrepreneurial activities.

This study identified that half and above half of the respondents invested their money from their personal savings and contributed in business up to rs.50,000. The main reason for starting business among Women Entrepreneurs is generating employment opportunities to others. Training programmes has a strong influence in gaining benefits among women entrepreneurs. Women Entrepreneurs in Chennai district have low strength significance level of awareness towards all schemes except Stree Shakthi Package scheme. The sources of awareness is highly created by Social media networking.

There are few potential Women Entrepreneurs remains latent due to this lack of awareness. Steps has to be taken by government in order to make various schemes and assistances to reach Women Entrepreneurs and monitor the effectiveness of these schemes. 


\section{REFERENCES}

[1] Dr. A.S.Shiralashetti (March 2013)-Awareness level towards Government schemes -A study of Women Entrepreneurs of north Karnataka districts- Volume V Issue-1- Summer Internship Society- PP 24-33

[2] Ms. G.Jayashree ; Dr. I. Carmel Mercy Priya- November 2016-International Journal of Social Relevance \& Concern-ISSN-2347-9698- Volume 4 Issue 11.

[3] M.Mahendran, R.Rajan Babu- April 2015-Financial support and schemes availed to women entrepreneurs in nagapattinam district Tamil Nadu-Volume:2, Issue:4, PP171-174www.allsubjectjournal.com-e-ISSN: 2349-4182-p-ISSN: 2349-5979- International Journal of Multidisciplinary Research and Development-Impact Factor: 3.762

[4] S O Junare, Ranjana Singh- 2016- Technological Understanding and Usage vis-à-vis Knowledge of Government Schemes - A Study of Women Entrepreneurs of selected Cities of Gujarat- Volume 1 Issue 1 - Amity Journal of Entrepreneurship.

[5] [5] Dr. Shrikrishna S. Mahajan, Mr. Chandrakant B.Kamble-2011- Government Support to Women Entrepreneurship: A Study of Programmes Implemented By MAVIM .- Vol.1,Issue.XIpp.1-4- ISSN:-2230-7850- Indian Streams Reserach Journal.

[6] Dr. Rajesh Chatterjee, Amit Kr. Deb - August 2017- Effect of Government programmes on Entrepreneurship: A study on Ne India with special reference to Tripura- Volume - 5, Issue- 8e-ISSN : 2347 - 9671| p- ISSN : 2349 - 0187- EPRA International Journal of Economic and Business Review- SJIF Impact Factor(2016) : 6.484.

[7] Mr. R. Paulmoni, Dr. P Geetha- A Study on Women Entrepreneurs Awareness about Government Schemes - Special Reference to Kanniyakumari District- International Journal of Business and Management Invention (IJBMI) ISSN (Online): 2319 - 8028, ISSN (Print): 2319 - 801X www.ijbmi.org -Volume 8 Issue 02 Series. IV - February 2019 - PP 01-07.

[8] Haris Abrar Kashmiri, Rubeena Akhter-2017-Role of Government policy in Entrepreneurship development- Vol. 25, No. 1.

[9] M. Uma, Arthi Arulmoorthy -2019- A Study on Entrepreneurs Awareness Towards Central Government Schemes- Volume 6, Issue 2 -E-ISSN 2348-1269, P- ISSN 2349-5138www.ijrar.org

[10] Satish KumarAmlathe, Prof. Rajesh Mehrotra- 2017- Opportunities \& Challenges of Women Entrepreneurship: An overview- IOSR Journal of Business and Management (IOSR-JBM)- eISSN: 2278-487X- p-ISSN: 2319-7668. Volume 19, Issue 3. Ver. IV - (PP 99-104 www.iosrjournals.org.

[11] Firdouse Rahman Khan- April 2015 - Women Entrepreneurship in Chennai, India - Factors Trigger and Prevent- International Journal of Management, Innovation \& Entrepreneurial Research Vol 1 (1), pg 29-43 